\title{
Front Matter: Volume 8456
}

, "Front Matter: Volume 8456," Proc. SPIE 8456, Nanophotonic Materials IX, 845601 (15 October 2012); doi: 10.1117/12.2011736

SPIE Event: SPIE NanoScience + Engineering, 2012, San Diego, California, United SPIE. States 


\title{
PROCEEDINGS OF SPIE
}

\section{Nanophotonic Materials IX}

\author{
Stefano Cabrini \\ Taleb Mokari \\ Editors
}

15-16 August 2012

San Diego, California, United States

Sponsored and Published by

SPIE

Volume 8456 
The papers included in this volume were part of the technical conference cited on the cover and title page. Papers were selected and subject to review by the editors and conference program committee. Some conference presentations may not be available for publication. The papers published in these proceedings reflect the work and thoughts of the authors and are published herein as submitted. The publisher is not responsible for the validity of the information or for any outcomes resulting from reliance thereon.

Please use the following format to cite material from this book:

Author(s), "Title of Paper," in Nanophotonic Materials IX, edited by Stefano Cabrini, Taleb Mokari, Proceedings of SPIE Vol. 8456 (SPIE, Bellingham, WA, 2012) Article CID Number.

ISSN: 0277-786X

ISBN: 9780819491732

Published by

SPIE

P.O. Box 10, Bellingham, Washington 98227-0010 USA

Telephone +1 3606763290 (Pacific Time) · Fax +1 3606471445

SPIE.org

Copyright (C) 2012, Society of Photo-Optical Instrumentation Engineers.

Copying of material in this book for internal or personal use, or for the internal or personal use of specific clients, beyond the fair use provisions granted by the U.S. Copyright Law is authorized by SPIE subject to payment of copying fees. The Transactional Reporting Service base fee for this volume is $\$ 18.00$ per article (or portion thereof), which should be paid directly to the Copyright Clearance Center (CCC), 222 Rosewood Drive, Danvers, MA 01923. Payment may also be made electronically through CCC Online at copyright.com. Other copying for republication, resale, advertising or promotion, or any form of systematic or multiple reproduction of any material in this book is prohibited except with permission in writing from the publisher. The CCC fee code is $0277-786 \mathrm{X} / 12 / \$ 18.00$.

Printed in the United States of America.

Publication of record for individual papers is online in the SPIE Digital Library.

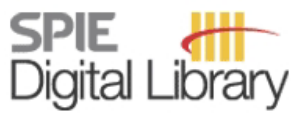

SPIEDigitalLibrary.org

Paper Numbering: Proceedings of SPIE follow an e-First publication model, with papers published first online and then in print and on CD-ROM. Papers are published as they are submitted and meet publication criteria. A unique, consistent, permanent citation identifier (CID) number is assigned to each article at the time of the first publication. Utilization of CIDs allows articles to be fully citable as soon as they are published online, and connects the same identifier to all online, print, and electronic versions of the publication. SPIE uses a six-digit CID article numbering system in which:

- The first four digits correspond to the SPIE volume number.

- The last two digits indicate publication order within the volume using a Base 36 numbering system employing both numerals and letters. These two-number sets start with 00, 01, 02, 03, 04, $05,06,07,08,09,0 A, 0 B \ldots 0 Z$, followed by 10-1Z, 20-2Z, etc.

The CID number appears on each page of the manuscript. The complete citation is used on the first page, and an abbreviated version on subsequent pages. Numbers in the index correspond to the last two digits of the six-digit CID number. 


\section{Contents}

$\checkmark \quad$ Conference Committee

\section{SESSION 1 SYNTHESIS AND CHARACTERIZATION I}

845602 Localized surface plasmon resonance of degenerate semiconducting nanocrystal ensembles with various shape distributions (Invited Paper) [8456-1]

R. J. Mendelsberg, Lawrence Berkeley National Lab. (United States) and Argonne National Lab. (United States)

$845603 \mathrm{Eu}^{3+}$ as optical probe of the structure in amorphous and nanocrystalline $\mathrm{ZnO}$ sol-gel films [8456-2]

E. Terán-Hinojosa, J. A. García-Macedo, Univ. Nacional Autónoma de México (Mexico);

G. Valverde-Aguilar, Instituto Politécnico Nacional (Mexico)

\section{SESSION 2 FABRICATION AND APPLICATIONS I}

845606 Antenna integrated quantum cascade laser switchable via telecommunications wavelength probe beam [8456-6]

J. Kohoutek, A. Bonakdar, D. Dey, R. Gelfand, I. Hassani Nia, O. G. Memis, V. Fathipour,

H. Mohseni, Northwestern Univ. (United States)

845608 Plasmon resonance at extreme temperatures in sputtered Au nanoparticle incorporated $\mathrm{TiO}_{2}$ films [8456-8]

P. R. Ohodnicki Jr., T. D. Brown, M. P. Buric, J. P. Baltrus, B. Chorpening, National Energy Technology Lab. (United States)

\section{SESSION 3 FABRICATION AND APPLICATIONS II}

$84560 \mathrm{~A}$ Wavelength tunable properties of the perpendicular dual-grating guided-mode resonance filters [8456-10]

Y. Wu, Z. Xia, Z. Wang, R. Liu, P. Tang, G. Lv, H. Wu, Tongji Univ. (China)

$84560 \mathrm{C}$ Optomechanical beam steering by surface plasmon nanoantenna [8456-12]

A. Bonakdar, J. Kohoutek, H. Mohseni, Northwestern Univ. (United States)

8456 OD Photoconductivity and stabilization of dopamine embedded in sol-gel TiO2 matrix [8456-13]

G. Prado-Prone, Univ. Nacional Autónoma de México (Mexico); G. Valverde-Aguilar, Instituto Politécnico Nacional (Mexico); J. García-Macedo, P. Vergara-Aragón, Univ. Nacional Autónoma de México (Mexico) 
8456 OE High-resolution 3D woodpile structures by direct fs laser writing [8456-14]

I. Sakellari, Univ. of California, Berkeley (United States); E. Kabouraki, Foundation for Research and Technology-Hellas (Greece) and Univ. of Crete (Greece); D. Gray, Foundation for Research and Technology-Hellas (Greece); C. Fotakis, Foundation for Research and Technology-Hellas (Greece) and Univ. of Crete (Greece); A. Pikulin, N. Bityurin, Institute of Applied Physics (Russian Federation); M. Vamvakaki, Foundation for Research and Technology-Hellas (Greece) and Univ. of Crete (Greece); M. Farsari, Foundation for Research and Technology-Hellas (Greece)

8456 OF Fabrication of large area photonic crystal with surface modified silica spheres (Invited Paper) [8456-15]

B.-J. Kim, K.-S. Kang, Kyungil Univ. (Korea, Republic of)

\section{SESSION 4 SYNTHESIS AND CHARACTERIZATION II}

$8456 \mathrm{OH} \quad$ Low-temperature photocarrier dynamics in single-layer $\mathrm{MoS}_{2}$ flakes [8456-17]

T. Korn, G. Plechinger, S. Heydrich, M. Hirmer, F.-X. Schrettenbrunner, D. Weiss, J. Eroms,

C. Schüller, Univ. Regensburg (Germany)

$8456 \mathrm{0J}$ Surface-plasmon-mediated emission from glancing-angle-deposition-functionalized ZnO nanowires [8456-19]

D. C. Mayo, Fisk Univ. (United States) and Vanderbilt Univ. (United States); A. T. Mayo, A. Ueda, Z. Pan, Fisk Univ. (United States); H. Y. XU, Y. C. Liu, Northeast Normal Univ. (China); R. R. Mu, Fisk Univ. (United States)

8456 OK Nano-opto-mechanically modulated plasmonic nanoantenna-integrated quantum cascade laser [8456-31]

J. Kohoutek, D. Dey, A. Bonakdar, R. Gelfand, V. Fathipour, O. G. Memis, H. Mohseni, Northwestern Univ. (United States)

POSTER SESSION

8456 OM Diffusion of dye solution in the intermolecular nanostructure of polydimethylsiloxane [8456-21]

M. Saito, T. Nishimura, K. Sakiyama, M. Nakagawa, Ryukoku Univ. (Japan)

$8456 \mathrm{ON}$ Photoconductivity studies on amorphous and crystalline $\mathrm{TiO}_{2}$ and $\mathrm{TiO}_{2}: \mathrm{Eu}^{3+}$ thin films synthesized by sol-gel [8456-25]

P. Francisco-Santiago, J. A. García-Macedo, Univ. Nacional Autónoma de México (Mexico); G. Valverde-Aguilar, Instituto Politécnico Nacional (Mexico)

8456 OP Preparation of flexible optical waveguide film with refractive index tunability [8456-28] Y. K. Kwon, S. J. Noh, J. Y. Han, M. K. Suk, S. I. Heo, S. J. Jin, H. H. Ahn, Inha Univ. (Korea, Republic of); C. H. Ahn, Seoul National Univ. (Korea, Republic of)

$8456 \mathrm{OQ}$ The effectiveness of metal oxide nanocrystal-enhanced polymers as hardmasks for photolithography [8456-29]

M. A. Hockey, Q. Lin, E. Calderas, Brewer Science, Inc. (United States)

Author Index

iv 


\section{Conference Committee}

Symposium Chairs

David L. Andrews, University of East Anglia Norwich (United Kingdom)

James G. Grote, Air Force Research Laboratory (United States)

Symposium Cochairs

Satoshi Kawata, Osaka University (Japan)

Manijeh Razeghi, Northwestern University (United States)

Conference Chairs

Stefano Cabrini, Lawrence Berkeley National Laboratory (United States)

Taleb Mokari, Ben-Gurion University of the Negev (Israel)

Conference Program Committee

David L. Andrews, University of East Anglia Norwich (United Kingdom)

Angus J. Bain, University College London (United Kingdom)

Mireille H. Blanchard-Desce, Université de Rennes 1 (France)

Robert W. Boyd, University of Rochester (United States)

Zeno Gaburro, Università degli Studi di Trento (Italy)

Aaron W. Harper, The University of Southern California (United States)

Ghassan E. Jabbour, Arizona State University (United States)

François Kajzar, Polytechnical University of Bucharest (Romania)

Dmitri I. Kovalev, University of Bath (United Kingdom)

Paras N. Prasad, University at Buffalo (United States)

Dmitri Talapin, The University of Chicago (United States)

Younan Xia, Washington University in St. Louis (United States)

Session Chairs

1 Synthesis and Characterization I

Stefano Cabrini, Lawrence Berkeley National Laboratory

(United States)

2 Fabrication and Applications I

Adam M. Schwartzberg, Lawrence Berkeley National Laboratory

(United States) 
3 Fabrication and Applications II

Rueben J. Mendelsberg, Lawrence Berkeley National Laboratory (United States)

4 Synthesis and Characterization II

Stefano Cabrini, Lawrence Berkeley National Laboratory (United States) 